\title{
THE CURRENT SITUATION OF THE INSTRUCTION IN EXTRACURRICULAR SPORTS FOR STUDENTS FROM TRA VINH UNIVERSITY, VIETNAM
}

\author{
Kien Hau' ${ }^{1 \mathrm{i}}$, \\ Tran Thi Thanh Huyen', \\ Tran Thi Thu ${ }^{3}$, \\ Nguyen Quang Vinh ${ }^{4}$ \\ 1,2 Tra Vinh University, \\ Vietnam \\ ${ }^{3}$ Tay Nguyen University, \\ Vietnam \\ ${ }^{4} \mathrm{PhD}$, Ho Chi Minh City University \\ of Physical, Education and Sports, \\ Vietnam
}

\begin{abstract}
:
This study uses the sociological investigation method and direct interview in order to understand the current situation of the instruction in extracurricular sports at Tra Vinh University. The total area of the playground is $13,700 \mathrm{~m}^{2}$ with the ratio of $1.36 \mathrm{~m}^{2} / \mathrm{student}$. There are 11 lecturers and the ratio of student/lecturer is 915.18. There is still no regular program in extracurricular sports for Tra Vinh University students.
\end{abstract}

Keywords: instruction, extracurricular sports, students, Tra Vinh University

\section{Introduction}

Extracurricular sports offered at Tra Vinh University are voluntary to students, which are organized in forms of sports clubs, groups and individuals, and are suitable to students' interests, gender, age and health condition. This aims to target the goal of physical education in the way that creates a healthy playground for students, including improving their motor skills, seeking and fostering sports talents.

Extra-curricular sports at Tra Vinh University in recent years have been given special attention by the Rector Board in terms of the teaching content, form, organization and contests. The fact that more than 10,000 current full-time students at Tra Vinh University, who join sports, shows effectiveness and feasibility in the opening of such an

i Correspondence: vinhqn@upes.edu.vn 
extracurricular sports program. This is in line with students' increasing demand for taking part in entertainment activities apart from their study in class. Since then, more and more students have participated in extracurricular sports activities to improve their health. This offers conditions for them to learn from each other. All contribute to comprehensively personal growth towards the socio- economic development. However, in order to ensure that the program in extracurricular sports is able to effectively adopted and carried out in the coming time, it is necessary to renovate the content and form of extracurricular sports activities in accordance with the actual condition of the university including facilities, human resource and curriculum. In order to have a scientific and practical base for innovating the content and form of the organization of extracurricular sports activities, it is important to undertake an accurate and comprehensive study on the actual situation of extracurricular sports. Therefore, this study attempts to address this current issue with the topic on: "The Current Situation of the Instruction in Extracurricular Sports for Students from Tra Vinh University, Vietnam".

This study aims to provide information about the current situation of the teaching of extracurricular sports at Tra Vinh University in terms of facilities, teaching staff and curriculum. This is the basis for innovating the content and form of the organization of extracurricular sports at the university.

\section{Material \& methods}

This study applies the sociological investigation, interview, practical survey and statistical methods. The participants who involved in the survey consist of 11 lecturers of physical education at Tra Vinh University.

\subsection{Results}

\subsection{In the aspect of facilities}

Statistical data for facilities that serve extracurricular sports activities for Tra Vinh University students is illustrated in Table 1.

Table 1: The current situation of facilities that serve students' extracurricular sports activities at Tra Vinh University

\begin{tabular}{|l|c|c|c|c|c|}
\hline \multirow{2}{*}{ Facilities } & \multicolumn{5}{|c|}{ Results } \\
\cline { 2 - 6 } & Amount & Floor area $\mathbf{( m}^{2} \mathbf{)}$ & Quality & Hired & Available on the campus \\
\hline Multi-functional gymnasium & 01 & 2400 & Good & & $\mathrm{x}$ \\
\hline Artificial football playground & 01 & 3250 & Good & $\mathrm{x}$ & $\mathrm{x}$ \\
\hline Natural football playground & 02 & 3500 & Good & & $\mathrm{x}$ \\
\hline Volleyball playground & 04 & 800 & Good & & \\
\hline Basketball court & 01 & 840 & Good & & \\
\hline Swimming pool & 01 & 450 & Good & $\mathrm{x}$ & $\mathrm{x}$ \\
\hline Badminton court & 04 & 480 & Good & & \\
\hline Péntanque court & 02 & 800 & Good & & \\
\hline
\end{tabular}


SPORTS FOR STUDENTS FROM TRA VINH UNIVERSITY, VIETNAM

\begin{tabular}{|l|c|c|c|c|c|}
\hline \hline Table-tennis practice room & 01 & 580 & Good & & $\mathrm{x}$ \\
\hline Running lane $100 \mathrm{~m}-200 \mathrm{~m}$ & 01 & 400 & Good & & $\mathrm{x}$ \\
\hline High and long jump hole & 01 & 200 & Good & & $\mathrm{x}$ \\
\hline Total area & & 13.700 & & & \\
\hline Total number of students & & 10.067 & & & \\
\hline Ratio $\mathbf{~ m}^{2}$ /student & & 1.36 & & & \\
\hline
\end{tabular}

The data showed that:

Tra Vinh University has a multi-purpose gymnasium with an area of 2,400 $\mathrm{m}^{2}$, a natural football field of $3,500 \mathrm{~m}^{2}, 04$ volleyball courts with an area of $800 \mathrm{~m}^{2}, 04$ badminton courts with an area of $480 \mathrm{~m}^{2}, 02$ péntanque courts with an area of $800 \mathrm{~m}^{2}, 01$ table tennis practice room with an area of $580 \mathrm{~m}^{2}$ and 01 artificial football field which is hired with an area of $3250 \mathrm{~m}^{2}$. In addition, the department of physical education has taken advantage of the available space for the teaching of martial arts and aerobics lessons. The abovementioned area basically meets the teaching activity of physical education on the campus. The ratio of the playground area is $1.36 \mathrm{~m}^{2} /$ student.

Pursuant to Decision No.2160/QD-TTg dated on November 11, 2013 on approving "The development plan of physical training and sports in Vietnam up to 2020, with a vision to 2030", the playground area for physical education and sports at all levels (m2/student) including professional and vocational secondary schools, colleges and vocational colleges and university reaches $02 \mathrm{~m}^{2}$ in 2015, $03 \mathrm{~m}^{2}$ in 2020 and $04 \mathrm{~m}^{2}$ in 2030 [ ]. Based on this decision and the number of students at Tra Vinh University, there is still a lack of space for offering the physical training. However, the physical education department has taken advantage of the available space on the campus, so it basically meets students' need.

In fact, the facilities and yard conditions to meet the requirements of instruction are very important to improve the quality of a subject, help learners to form and strengthen their motor skills, and increase the density of movement in physical education classes.

With the increasing trend of development and desire to improve the quality of education, the conditions of facilities for the instruction in physical education subjects are increasingly improved. In particular, the university has offered great conditions for the department of physical education to purchase equipment and tools to better serve the teaching of physical education for students.

\subsection{The current situation of faculty members}

The statistical data of lecturers who deliver extracurricular sports courses at Tra Vinh University is shown in Table 2. 
Table 2: The surveyed information on faculty members who take part in the teaching of extracurricular sports course at Tra Vinh University

\begin{tabular}{|c|c|c|c|c|}
\hline TT & Category & & Amount & Ratio (\%) \\
\hline \multirow{3}{*}{1} & \multirow{3}{*}{ Gender } & Male & 09 & $81.8 \%$ \\
\hline & & Female & 02 & $18.2 \%$ \\
\hline & & Total & 11 & $100 \%$ \\
\hline \multirow{4}{*}{2} & \multirow{4}{*}{ Age } & Below 30 & 01 & $9.1 \%$ \\
\hline & & From 30 to 40 & 06 & $54.5 \%$ \\
\hline & & Over 40 & 04 & $36.4 \%$ \\
\hline & & Total & 11 & $100 \%$ \\
\hline \multirow{4}{*}{3} & \multirow{4}{*}{ Qualification } & College/ Diploma & 00 & $0.0 \%$ \\
\hline & & Undergraduate & 04 & $36.4 \%$ \\
\hline & & Post-graduate & 07 & $63.6 \%$ \\
\hline & & Total & 11 & $100 \%$ \\
\hline \multirow{3}{*}{4} & \multirow{3}{*}{ Duty } & Visiting lecturers & 00 & $00 \%$ \\
\hline & & Regular lecturers & 11 & $100 \%$ \\
\hline & & Total & 11 & $100 \%$ \\
\hline \multirow{4}{*}{5} & \multirow{4}{*}{ Training professional } & Physical education & 08 & $72.7 \%$ \\
\hline & & Sports training & 02 & $18.2 \%$ \\
\hline & & Others & 01 & $9.1 \%$ \\
\hline & & Total & 11 & $100 \%$ \\
\hline \multirow{3}{*}{6} & \multirow{3}{*}{ Teaching content } & Suitable & 11 & $100 \%$ \\
\hline & & Unsuitable & 00 & $00 \%$ \\
\hline & & Total & 11 & $100 \%$ \\
\hline \multirow{5}{*}{7} & \multirow{5}{*}{ Teaching experience } & Below 10 years & 03 & $27.2 \%$ \\
\hline & & From $11-15$ years & 04 & $36.4 \%$ \\
\hline & & From $16-20$ years & 04 & $36.4 \%$ \\
\hline & & Over 20 years & 00 & $00 \%$ \\
\hline & & Total & 11 & $100 \%$ \\
\hline 8 & \multicolumn{2}{|l|}{ Student/ lecturer ratio } & \multicolumn{2}{|c|}{915.18} \\
\hline
\end{tabular}

The data in Table 2 show that:

Regarding gender, there are 9 males (accounting for 81.8\%), and 2 females (accounting for $18.2 \%$ ).

For age, the highest percentage is from 30 to 40 years old, accounting for $54.5 \%$; and the lowest is under 30 years old, accounting for $9.1 \%$, which is followed by over 40 years old with $36.4 \%$.

In terms of qualification, the postgraduate and undergraduate levels are $63.6 \%$ and $36.4 \%$, respectively. Moreover, $100 \%$ are full-time lecturers and the teaching content is relevant to their professional expertise.

In terms of professional, physical education accounts for $72.7 \%$, sports training is $18.2 \%$, and other specialties accounts for $9.1 \%$.

The teaching experience for those with $11-15$ years and $16-20$ years is $36.4 \%$, and under 10 years is $27.2 \%$.

As illustrated in the description, it is clear that Tra Vinh University has 11 full-time lecturers in physical education and sports with the appropriate professional skills. Most 
of them are males $(81.8 \%)$, in which the postgraduate qualification is $63.6 \%$, and the profession is in physical education (72.7\%). Lastly, the teaching experience over 30 years old is $90.9 \%$, whereas that over 10 years is $72.8 \%$.

The student/faculty member ratio is 915.18. However, Decision No. 2160/QD-TTg dated on November 11, 2013 on the approval of "The development plan of sports and physical education in Vietnam by 2020, with a vision to 2030 " states that the ratio of physical education lecturers to university students has to reach $1 / 500$ in 2015, 1/400 in 2020 and 1/300 in 2030 [ ]. Compared with this target, this current ratio at Tra Vinh University (01 teacher/915.18 students) has not yet satisfied.

Moreover, lecturers who hold the bachelor's degree need to do master's degree to enhance their professional qualification and also to meet the standard prescribed in the 2018 Education Law.

Table 3: The lecturer survey result on the content and the instruction in extracurricular sports for Tra Vinh University students

\begin{tabular}{|c|c|c|c|c|c|}
\hline \multirow{2}{*}{ Content } & \multicolumn{2}{|c|}{ Sports that a lecturer will teach } & \multicolumn{2}{c|}{ Sports that a lecturer can potentially teach } \\
\cline { 2 - 6 } & Amount & $\mathbf{\%}$ & Amount & \% \\
\hline 1 & Football & 01 & 9.1 & 02 & 18.2 \\
\hline 2 & Volleyball & 02 & 18.2 & 02 & 18.2 \\
\hline 3 & Table tennis & 02 & 18.2 & 02 & 18.2 \\
\hline 4 & Badminton & 01 & 9.1 & 01 & 9.1 \\
\hline 5 & Athletics & 01 & 9.1 & 01 & 0.1 \\
\hline 6 & Martial arts & 01 & 9.1 & 01 & 9.1 \\
\hline 7 & Swimming & 01 & 9.1 & 01 & 9.1 \\
\hline 8 & Chess & 01 & 9.1 & 00 & 0.0 \\
\hline 9 & Péntanque & 01 & 100.0 & 01 & 9.1 \\
\hline \multicolumn{2}{|c|}{ Total } & 11 & & 11 & 100.0 \\
\hline
\end{tabular}

The data in Table 3 show that:

The equal highest number of lecturers who deliver the teaching and coaching in football and table tennis as their strengths is $18.2 \%$. Meanwhile, this figure for other sports of badminton, athletics, martial arts, swimming, chess and iron ball accounts for $9.1 \%$ with 01 lecturer/ each.

Lecturers who possibly deliver sports of table tennis, football and volleyball account for the highest percentage with equal $18.2 \%$, whereas that of badminton, athletics, martial arts, swimming, and iron ball is $01 /$ each $(9.1 \%)$. There are no lecturers who teach chess. 


\subsection{The current situation of the extracurricular educational program for students at Tra Vinh University}

Table 4: The content of the physical education program at Tra Vinh University

\begin{tabular}{|c|c|c|}
\hline No & Module and Credit & Content \\
\hline 1 & I (30 periods) & Physical education - 1 (Athletics) \\
\hline \multirow{4}{*}{2} & \multirow{4}{*}{ II (30 periods) } & Physical education -2 (Table tennis) \\
\hline & & Physical education -2 (Football) \\
\hline & & Physical education - 2 (International chess) \\
\hline & & Physical education - 2 (Taekwondo) \\
\hline \multirow{5}{*}{3} & \multirow{5}{*}{ III (30 periods) } & Physical education - 3 (Badminton) \\
\hline & & Physical education -3 (Volleyball) \\
\hline & & Physical education -3 (Chinese Chess) \\
\hline & & Physical education -3 (Swimming) \\
\hline & & Physical education - 3 (Péntanque) \\
\hline
\end{tabular}

The Table 4 above shows the statistics for the educational program of physical education at Tra Vinh University.

The statistics in Table 4 show that the program in physical education at Tra Vinh University consists of 03 credits with the total 90 periods. There are 03 modules with 01 credit/each. Module 1 is compulsory for students while modules 2 and 3 are elective, where students can choose to study table tennis, football, chess, Taekwondo (in module 2) and badminton, volleyball, chess and Péntanque (in module 3).

Regarding the extracurricular sports program, with the current state of facilities and human resource coupled with the fact that Tra Vinh University still has no appropriate mechanisms and policies for lecturers and students in extracurricular sports activities, these activities are mainly in form of sports team. In addition, clubs are also limited and students have to mainly do practice on their own, mostly with no guidance from the instructor. The content for practice is mainly jogging, badminton, football and volleyball in the dormitory area.

\section{Conclusions}

The total area of playground for the instruction in extracurricular sports at Tra Vinh University is $13,700 \mathrm{~m}^{2}$ (multi-purpose gymnasium, football field, volleyball court, badminton court, péntanque court, and table tennis practice room). The ratio of the yard area for sports training is $1.36 \mathrm{~m}^{2} /$ student.

The current situation indicates that the number of lecturers who teach extracurricular sports at Tra Vinh University is 11, all of whom are full-time and have appropriate profession in physical education (72.7\%) and qualified postgraduate degree (63.6\%). In addition, most of them are males $(81.8 \%)$, and those who are above 30 years old account for $90.9 \%$. The percentage of lecturers who are over 10 years of teaching experience is $72.8 \%$. Finally, the student/faculty member ratio is 915.18 . 
The current situation indicates that there is no official extracurricular sports program for students at Tra Vinh University.

\section{Conflict of Interest Statement}

The authors declare no conflicts of interests.

\section{About the Authors}

Kien Hau has been a physical education teacher at Tra Vinh University, Vietnam.

Tran Thi Thanh Huyen has been working as a physical education teacher at Tra Vinh University, Vietnam.

Tran Thi Thu has been working as a physical education teacher at Tay Nguyen University, Vietnam.

Nguyen Quang Vinh is Associate Professor, Academic Affairs, Ho Chi Minh University of Physical Education and Sports. His research interests include physical education, teachers' beliefs and PE curriculum planning.

\section{References}

Politburo (2017), Resolution No. 20-NQ/TW, dated on October 25, 2017 on strengthening protection and improvement of people's healthcare in the new situation.

The Ministry of Education and Training (2008), Decision No. 72/2008/QD-BGDDT, dated on December 23, 2008 on promulgating the regulations on organizing extracurricular sports activities for students.

The Ministry of Education and Training (2015), Circular No. 25/2015/BGDDT, dated on October 14, 2015 on adopting the regulations on the undergraduate curriculum in physical education.

Prime Minister (2010), Decision No. 2198/QD-TTg dated on December 3, 2010 on approving the Development strategy for physical education and sports in Vietnam upto 2020.

Prime Minister (2013), Decision No. 2160/QD-TTg dated on November 11, 2013 on approving the Development plan of physical training and sports in Vietnam up to 2020, with a vision to 2030.

Prime Minister (2011), Decision No. 641/QD-TTg, dated on April 28, 2011 on approving the Master plan on the development of physical strength and stature of Vietnamese people in the period 2011 - 2030.

Prime Minister (2016), Decision 1076/QD-TTg, dated on June 17, 2016 on approving the Project on the development of physical education and school sports for the period 2016-2020, with an orientation to 2025. 
Kien Hau, Tran Thi Thanh Huyen, Tran Thi Thu, Nguyen Quang Vinh

THE CURRENT SITUATION ABOUT THE INSTRUCTION IN EXTRACURRICULAR

SPORTS FOR STUDENTS FROM TRA VINH UNIVERSITY, VIETNAM

Creative Commons licensing terms

Authors will retain the copyright of their published articles agreeing that a Creative Commons Attribution 4.0 International License (CC BY 4.0) terms will be applied to their work. Under the terms of this license, no permission is required from the author(s) or publisher for members of the community to copy, distribute, transmit or adapt the article content, providing a proper, prominent and unambiguous attribution to the authors in a manner that makes clear that the materials are being reused under permission of a Creative Commons License. Views, opinions and conclusions expressed in this research article are views, opinions and conclusions of the author(s). Open Access Publishing Group and European Journal of Physical Education and Sport Science shall not be responsible or answerable for any loss, damage or liability caused in relation to/arising out of conflict of interests, copyright violations and inappropriate or inaccurate use of any kind content related or integrated on the research work. All the published works are meeting the Open Access Publishing requirements and can be freely accessed, shared, modified, distributed and used in educational, commercial and non-commercial purposes under a Creative Commons attribution 4.0 International License (CC BY 4.0). 